\title{
The Social Life of Entanglements
}

\author{
International Investment and Human Rights Norms in \\ and beyond ISDS
}

\author{
FRANCESCO CORRADINI
}

\subsection{Introduction}

Metaphors may be helpful tools to think about law. They may also help us to imagine what happens when law makes its actual appearance in the plural rather than in the singular. Consider the following statement:

[W] estbrook's intriguing metaphor of cream poured into coffee, swirling and billowing before blending into a homogenized liquid, is suggestive. But this only captures part of what we should be concerned with. The cream comes from a single outside source, it is poured from above, the flow is in one direction, and the blending is relatively harmonious; but many of our stories of diffusion of law are more complex often involving two or more reciprocally interacting change agents, crossing of levels, and repression, resistance, or avoidance. ${ }^{1}$

A former judge of the International Court of Justice (ICJ) employed a similar rhetorical device as he imagined how investment protection and human rights norms could be brought in relation. He observed:

[O]il and water do not mix, at least not readily. Is this also true of human rights and the protection of foreign investment-here also in the sense that they ought to be kept apart? Some observers, or rather stakeholders, might think so. There is, of course a way to overcome this separation: science

I am grateful to Nico Krisch for his constructive comments and criticism on earlier versions of this work. I also thank Tomáš Morochovič for his careful editing and helpful suggestions on this text. I gratefully acknowledge financial support by the Swiss National Science Foundation, which made this research possible.

${ }^{1}$ W. Twining, 'Diffusion and Globalization Discourse Symposium: Diffusion of Law in the 21st Century: Interaction and Influence' (2006) 47 Harvard International Law Journal 507-16. 
and industry employ some sort of mediators between the water and the oil (so-called 'emulgators') to achieve this. ${ }^{2}$

From a legal theory perspective, the observation of contemporary phenomena akin to the interactions captured by these metaphors has led to the hypothesis that, particularly in contexts of societal disagreement and institutional pluralization, law has become 'entangled'. International legal scholarship has diagnosed similar dynamics in disputes over the relationship between global economic governance and human rights. ${ }^{4}$ From this perspective, efforts to establish human rights obligations for multinational corporations in 2003, followed by the UN Guiding Principles in 2011 and leading to current discussions at the UN about a new international instrument on transnational corporations, ${ }^{5}$ may be seen as fragments belonging to a common dynamic process of defining relations between business and human rights norms. ${ }^{6}$

To illustrate this process, this chapter investigates forms of interaction between international investment and human rights law. As these forms depend on the contexts in which they are construed, I focus on governance sites where actors have disagreed about the best way to order the encounter of multiple legalities. Examining the 'social life' of this encounter, I seek to understand when and how 'entangled legalities"7 emerge where, how and by whom have they been produced? Drawing upon the conceptual framework of the volume, I analyse competing claims of actors and institutions through which investment protection and human rights norms have been brought in relation over time.

The chapter has three sections, in addition to an introduction and a conclusion. Section 7.2 identifies the rational and ideational parameters

${ }^{2}$ B. Simma, 'Foreign Investment Arbitration: A Place for Human Rights?' (2011) 60 International \& Comparative Law Quarterly 573-96.

${ }^{3}$ See Chapter 1.

${ }^{4}$ P. Alston, 'Resisting the Merger and Acquisition of Human Rights by Trade Law: A Reply to Petersman' (2002) 13 European Journal of International Law 815-44; see also, in the context of the interface between trade and environment, Chapter 8.

${ }^{5}$ OEIGWG Chairmanship, 'Second Revised Draft, Legally Binding Instrument to Regulate, in International Human Rights Law, the Activities of Transnational Corporations and Other Business Enterprises' (6 August 2020) www.ohchr.org/Documents/HRBodies/ HRCouncil/WGTransCorp/Session6/OEIGWG_Chair-Rapporteur_second_revised_ draft_LBI_on_TNCs_and_OBEs_with_respect_to_Human_Rights.pdf.

${ }^{6}$ N. Krisch, F. Corradini and L. Lu Reimers, 'Order at the Margins: The Legal Construction of Interface Conflicts Over Time' (2020) 9 Global Constitutionalism 343-63.

7 See Chapter 1. 
that are likely to affect whether and how 'forms of entanglement' ${ }^{8}$ in international investment law have come about and developed. On the one hand, these forms may be an effect of competing interests of actors with unequal access to resources and knowledge to shape and organize them. Rational actors' attitudes towards what they represent as 'other' legalities may depend upon the potential gains involved in that determination. On the other hand, actors' mindsets and the cultural setting of investment arbitration are bound to have repercussions on how the boundaries of international investment law and its relations with competing legalities are shaped. Against this background, Section 7.3 examines how actors have actually dealt with multiple legalities, in particular with human rights norms, in the context of investor-state dispute settlement (ISDS) and analyses the various forms that they have generated there. As actors' responses to multiplicity have varied considerably in practice, the emerging picture is not coherent. When interpreting investment treaty standards, investment adjudicators have disregarded human rights norms in some cases, while in other cases they accorded them some weight, but always doing so from the perspective of their own legality. Actors' strategic interests and ideational context may partly account for the diversity of interpretive practices observed. As the institutions of international investment protection face growing challenges from national governments, academics and nongovernmental actors, linkages with human rights may be beneficial to their cause.

Section 7.4 examines similar dynamics of convergence and divergence between legalities in contexts of international investment law reform, where the norm of ISDS itself has become the object of acute contestation. Human rights experts have articulated a mode of ordering multiplicity that is similar to the dominant forms of relationing observed in foreign investment litigation. Associated as they are to a systemic vision of order, human rights lawyers have also relied on norms of internal hierarchy according to which different legalities have to be 'consistent' with human rights and the rule of law. Some of these experts went so far as to claim that human rights norms have priority over conflicting legalities.

${ }^{8}$ See Chapter 1. For the purpose of this chapter, I use 'entanglement' and 'enmeshment' interchangeably. 


\subsection{Pathways to Entanglement in International Investment Governance Sites}

Legal scholars have emphasized the pluralist, decentralized and incrementally evolving character of international investment law. ${ }^{9}$ Indeed, in contexts of investment treaty disputes, often this law makes its appearance more in the plural than in the singular. ${ }^{10}$ For example, bilateral investment treaties (BITs), multilateral or regional trade and investment agreements often interplay with domestic laws, contractual frameworks and other rules of international law and therefore it becomes crucial to define their relations. ${ }^{11}$ At sites of foreign investment governance, entanglements do not build themselves but are defined by the interplay of situated actors with competing stakes and normative orientations. ${ }^{12}$ Such diversity of actors and 'bodies of norms ${ }^{13}$ makes this arena of global economic governance, and investment treaty arbitration in particular, ${ }^{14}$ an ideal setting to analyse how entangled legalities are formed and operate. The purpose of this chapter is to get closer to the social life of relations built in and around this law. To do so, I consider how actors' attitudes towards human rights norms in investor-state arbitration may respond to competing interests and the ideational background in which they are formed.

\subsubsection{Competing Interests}

Societal actors' interests are a first potential determinant of entangled legalities. ${ }^{15}$ From a rational choice perspective, international investment

9 J. Pauwelyn, 'Rational Design or Accidental Evolution? The Emergence of International Investment Law', in Z. Douglas, J. Pauwelyn and J. E. Viñuales (eds), The Foundations of International Investment Law: Bringing Theory into Practice (Oxford University Press, 2014), pp. 11-43; A. Roberts, 'Clash of Paradigms: Actors and Analogies Shaping the Investment Treaty System' (2013) 107 The American Journal of International Law 45-94.

10 Z. Douglas, 'The Hybrid Foundations of Investment Treaty Arbitration' (2003) 74 British Yearbook of International Law 151-289, referring to the 'laws applicable to an investment dispute' at 194.

${ }^{11}$ J. Viñuales, 'Sources of International Investment Law: Conceptual Foundations of Unruly Practices', in S. Besson and J. d'Aspremont (eds), Oxford Handbook on the Sources of International Law (Oxford University Press, 2017).

12 See Chapter 1, Section 1.4.1.

${ }^{13}$ On this notion, see Chapter 1, Section 1.2.

14 On ISDS as a mechanism and form of global governance, see S. Schill, 'W(h)ither Fragmentation? On the Literature and Sociology of International Investment Law' (2011) 22 European Journal of International Law 875-908.

15 See Chapter 1, Section 1.4.1. 
arbitration participants - foreign investors, host governments, investment arbitrators, lawyers and non-governmental organizations (NGOs) - act rationally to maximize their self-interest. ${ }^{16}$ Given the competition of interests and concerns involved, conflicting demands and priorities are bound to condition whether and how norms will be brought together or kept apart. ${ }^{17}$ This outcome may depend on actors' 'prudential reasons-for-action' - different actors will shape forms of relation depending on their own expected gains. ${ }^{18}$

Since 'states, investors, and NGOs often favour different paradigms in light of their divergent normative interests and agendas', ${ }^{19}$ these interests and agendas will also determine what weight they will give to the legalities at play. I assume that the interest of the two disputing parties foreign investor and responding state - is to win the dispute. As investors argue 'for broad investor rights, ${ }^{20}$ we can expect them to defend their own interests from the potentially disruptive effects of human rights protecting the interests of other individuals or groups. Empirical findings suggest that foreign investors have benefited from investment litigation. Particularly since the second half of 1990s, they have gained from using investment claims against poor and rich governments. ${ }^{21}$ The stability and predictability of international investment protection - legally sanctioned through international arbitration - has been economically beneficial to international investors. It seems that the status quo has protected foreign investors' interests against the preferences of other societal actors. ${ }^{22}$ Given the beneficial environment in which investors bring their claims, couplings with bodies of norms of different origin may open unpredictable scenarios. As rational actors, foreign investors will seek to resist this

${ }^{16}$ J. Bonnitcha, L. N. S. Poulsen and M. Waibel, The Political Economy of the Investment Treaty Regime (Oxford University Press, 2017), at 127.

${ }^{17}$ On the competition of interests involved, see M. Sornarajah, The International Law on Foreign Investment (Cambridge University Press, 2017), 'Introduction'.

18 T. Schultz, Transnational Legality: Stateless Law and International Arbitration (Oxford University Press, 2014), pp. 26-30.

19 Roberts, 'Clash of Paradigms', 48.

${ }^{20}$ J. Pauwelyn, 'The Rule of Law without the Rule of Lawyers? Why Investment Arbitrators Are from Mars, Trade Adjudicators from Venus' (2015) 109 American Journal of International Law 761-805, at 782.

21 T. Schultz and C. Dupont, 'Investment Arbitration: Promoting the Rule of Law or Overempowering Investors? A Quantitative Empirical Study' (2015) 25 European Journal of International Law 1147-68.

22 N. Tzouvala, 'The Academic Debate about Mega-Regionals and International Lawyers: Legalism as Critique?' (2018) 6 London Review of International Law 189-209, at 200. 
outcome. ${ }^{23}$ However, in cases in which it is convenient to them, they may also entangle their rights with human rights norms, perhaps to enhance the persuasiveness of their claims against the host government. ${ }^{24}$ States, too, may expect gains from these types of connections. Frequently, and especially in times of economic crises, linkages with human rights might strengthen their defences against investor's claims. Countries with limited financial resources may use these linkages as a rhetorical strategy to expand their 'regulatory authority ${ }^{25}$ and avoid costly liability or reduce the amount of compensation due to the investor. Finally, NGOs (other than business associations) and human rights experts may entangle international investment and human rights law to advance the interests of affected outsiders like local communities and human rights holders.

Investment arbitration insiders' decision-making may also respond to constraints and incentives. ${ }^{26}$ Previous empirical analysis has concluded that arbitrators of the International Centre for Settlement of Investment Disputes (ICSID) form a 'network' that 'reinforces prevailing norms and behaviours and insulates its most important members from outside influence. ${ }^{27}$ Beyond international arbitrators, legal counsel, expert witnesses and tribunal secretaries have also become particularly influential actors. ${ }^{28}$ In conditions of professional competition, the members of the investment arbitration industry may have professional incentives to distance human rights. As co-operators of the system, they will have material incentives to defend their legal specialization and their role as the masters of its law. From their perspective, investment arbitration may be a specialized profession with its own 'ethos' and associated relevant

23 '[I]nvestors will not invoke the kind of international law that may weaken their legal position', A. van Aaken, 'Fragmentation of International Law: The Case of International Investment Protection' (2008) 17 Finnish Yearbook of International Law 91-130, at 93.

24 On the 'strategic function of human rights references in investment arbitration', see S. Steininger, 'What's Human Rights Got To Do With It? An Empirical Analysis of Human Rights References in Investment Arbitration' (2018) 31 Leiden Journal of International Law 33-58, at 45-9.

25 Pauwelyn, 'The Rule of Law', at 782.

26 T. Schultz, 'Arbitral Decision-Making: Legal Realism and Law and Economics' (2015) 6 Journal of International Dispute Settlement 231-51.

27 S. Puig, 'Social Capital in the Arbitration Market' (2014) 25 European Journal of International Law 387-424, at 390.

${ }^{28}$ M. Langford, D. Behn and R. H. Lie, 'The Revolving Door in International Investment Arbitration' (2017) 20 Journal of International Economic Law 301-32. 
frameworks and practices. ${ }^{29}$ Therefore, distancing human rights may be needed to secure reputation from other members of their community of practice and to continue their practice as usual. ${ }^{30}$ Yet empirical work has found that over time there have been incentives for these legal experts to be reflexively open to societal demands. As investor-state arbitration faces a legitimacy crisis, some arbitrators may act strategically to 'manage consciously or unconsciously the legitimacy of arbitration' by showing 'greater deference to respondent states'. ${ }^{31}$ To do so, they might seek to adjust their decision-making in response to the claims and interests of dominant states like the European Union, the United States and China, but also to those of some Latin America countries that have been vocal against investment arbitration. In this context, investment arbitration officials might benefit from linkages with norms with strong social backing like human rights law to strengthen their own legitimacy. ${ }^{32}$

\subsubsection{Ideational Contexts}

A second possible cause of entanglements is the ideational context in which they come about. In investment arbitration, this context is shaped by multiple factors, including actors' 'shared understandings' of international investment law and their role in the 'community of practice' they form a part of. ${ }^{33}$ 'Epistemic communities - that is, social groups of professionals and academics that shape the discursive policies ${ }^{34}$ in investment arbitration have played a role in the formation of those understandings, ${ }^{35}$ with possible implications for the 'interface norms' and practices emerging from the inside of that community of practice and its discourse. From this perspective, situations of enmeshment may

29 T. Schultz, 'The Ethos of Arbitration', in T. Schultz and F. Ortino (eds), Oxford Handbook of International Arbitration (Oxford University Press, 2020).

30 Schultz, 'Arbitral Decision-Making'.

${ }^{31}$ M. Langford and D. Behn, 'Managing Backlash: The Evolving Investment Treaty Arbitrator?' (2018) 29 European Journal of International Law 551-80.

32 See Chapter 1, Section 1.2. See also Steininger, 'What's Human Rights', at 49-50.

33 See Chapter 1, Section 1.2. On the concepts of 'shared understanding' and 'communities of practice', see J. Brunnée and S. Toope, 'Interactional International Law: An Introduction' (2011) 3 International Theory 307-18.

34 A. Bianchi, 'Epistemic Communities in International Arbitration', in T. Schultz and F. Ortino (eds), The Oxford Handbook of International Arbitration (Oxford University Press, 2020).

35 Roberts, 'Clash of Paradigms'; E. Gaillard, 'Sociology of International Arbitration' (2015) 1 Arbitration International 1-17. 
be driven by how different actors regard international investment law, for example by adopting primarily an international public law, commercial arbitration or public law approach. ${ }^{36}$

Investment tribunals will often understand their role as strictly confined to the determination of whether foreign investors' rights have been violated or not. In that determination, arbitrators will see themselves primarily as interpreters of the legal basis creating those rights (e.g. a treaty), with implications for their room for manoeuvre to create relations with bodies of norms perceived as external. ISDS participants' choice of 'conceptual maps ${ }^{37}$ is likely to impact whether and how legalities are brought together or kept apart and with which effects. This choice may depend upon actors' background and projects. For instance, investment arbitrators with knowledge in public international law have drawn on the judgements of the ICJ, while others with experience in trade law have relied on the World Trade Organization (WTO) jurisprudence. $^{38}$ The same holds true for arbitrators emphasizing a 'universalistic' versus 'particularistic' perspective of the interaction between 'general international law' and other 'special regimes'. For example, a former ICJ judge has situated 'international investment law' within 'general international law' in keeping with his vision about the relationship between 'special regimes' within the wider 'universe of international law. ${ }^{39}$ Similarly, lawyers believing in a unified 'international legal system' as opposed to a 'fragmented' one will consider linkages between international investment and human rights law with less hesitancy. ${ }^{40}$

However, previous sociological analysis of the investment arbitration culture' has concluded that lawyers with a strong background in public international law are the minority in investment arbitration settings while the 'commercial arbitration paradigm' appears as the dominant

${ }^{36}$ Roberts, 'Clash of Paradigms'.

37 Ibid.

${ }^{38}$ Ibid., at 55 .

39 Simma, 'Foreign Investment Arbitration'. B. Simma and J. Kill, 'Harmonizing Investment Protection and International Human Rights: First Steps Towards a Methodology', in C. Binder, U. Kriebaum, A. Reinisch and S. Wittich (eds), International Investment Law for the 21st Century: Essays in Honour of Christoph Schreurer (Oxford University Press, 2009), pp. 679-707.

40 P.-M. Dupuy, 'Unification Rather than Fragmentation of International Law? The Case of International Investment Law and Human Rights Law', in P.-M. Dupuy, E.-U. Petersmann and F. Francioni (eds), Human Rights in International Investment Law and Arbitration (Oxford University Press, 2009), pp. 45-62. 
one. ${ }^{41}$ Empirical work on the composition of investor-state arbitral tribunals at ICSID has found that these tribunals comprise individuals mostly men from the USA and Europe - whose conception of law reflects their particular training and professional background. ${ }^{42}$ Here, international 'business lawyers' with competence in 'commerce, industry or finance' appear as the dominant players. ${ }^{43}$ The investment arbitration community seems to have little knowledge of human rights law due to the particular 'sociocultural features' and processes of socialization of that community. ${ }^{44}$ Indeed, 'culture influences how people think, communicate, behave, ${ }^{45}$ including how they situate themselves in relation to different constituencies and their legalities. However, legal culture and socio-psychological influences ${ }^{46}$ are not the only elements of the ideational context in which arbitrators' decision-making is situated. Empirical work has found that arbitrators' 'policy preferences', including their ideology, also shape their decisions. ${ }^{47}$ As a consequence of the 'set of values and beliefs ${ }^{\prime 48}$ that seem dominant in investment arbitration we might expect resistance to tight linkages with human rights, ${ }^{49}$ although it is possible that investment arbitrators' 'background preferences ${ }^{\text {'50 }}$ might begin to change.

\subsection{Navigating Multiplicity in ISDS Practice}

\subsubsection{Varying Forms of Relation}

As claims about human rights have begun to be heard in investment arbitration, ISDS participants have faced the challenge of 'navigating'

${ }^{41}$ M. Hirsch, 'The Sociological Dimension of International Arbitration: The Investment Arbitration Culture', in T. Schultz and F. Ortino (eds), Oxford Handbook of International Arbitration (Oxford University Press, 2020).

42 Pauwelyn, 'The Rule of Law'.

${ }^{43}$ Puig, 'Social Capital', 402.

${ }^{44}$ M. Hirsch, Invitation to the Sociology of International Law (Oxford University Press, 2015), pp. 129-55.

45 Ibid., p. 131.

${ }^{46}$ M. Gicquello, 'The Reform of Investor-State Dispute Settlement: Bringing the Findings of Social Psychology into the Debate' (2019) 10 Journal of International Dispute Settlement 561-81.

${ }^{47} \mathrm{M}$. Waibel and Y. Wu, 'Are Arbitrators Political? Evidence from International Investment Arbitration?' (2017) www.yanhuiwu.com/documents/arbitrator.pdf.

${ }^{48}$ Gaillard, 'Sociology of International Arbitration'.

${ }^{49}$ Hirsch, Invitation to the Sociology.

${ }^{50}$ Langford and Behn, 'Managing Backlash'. 
between multiple bodies of norms. ${ }^{51}$ Influenced by the discourse of institutions like the World Bank-based ICSID, the Permanent Court of Arbitration (PCA) or the United Nations Commission on International Trade Law (UNCITRAL), ISDS has become one among many governance sites where 'horizontal' and 'vertical' interactions between legal orders have been articulated over time. At this site, ad hoc investment arbitrators have become key decision-makers in setting the boundaries of 'international investment law'. ${ }^{52}$ While scholars have observed an increase in the number of actors' statements referring to human rights norms in investment litigation, ${ }^{53}$ we know less about the forms of relation constructed through those claims. In Section 7.3.2, I draw on a selection of statements to analyse the ways in which different actors have brought bodies of norms in relation in ISDS.

\subsubsection{Hierarchies and Separation}

Foreign investors and states have dealt with multiplicity by relying on hierarchies, as exemplified in the CMS Gas Transmission Company case. $^{54}$ The dispute arose after Argentina adopted measures to protect the welfare of the population, including by guaranteeing access to public services, amid an economic crisis at the end of the 1990s. At the time, CMS, a US corporation with an investment in the gas transportation sector of Argentina, claimed it suffered financial losses as a result of those exceptional measures and invoked its rights under the Argentina-United States BIT to protect its interests through ICSID arbitration. While Argentina and CMS disagreed over the ultimate source of authority to decide their dispute, they both referred to norms about hierarchy to order the relation between bodies of norms. Particularly contentious

51 See Chapter 1.

52 J. E. Alvarez, Boundaries of Investment Arbitration: The Use of Trade and European Human Rights Law in Investor-State Disputes (Juris, 2018). Already in 1990, the AAPL tribunal stated that an investment treaty 'is not a self-contained closed legal system limited to provide for substantive material rules of direct applicability, but it has to be envisaged within a wider juridical context in which rules from other sources are integrated through implied incorporation methods, or by direct reference to certain supplementary rules, whether of international character or of domestic law nature'. Asian Agricultural Products Ltd v. Republic of Sri Lanka, ICSID Case No ARB/87//3, Award, 27 June 1990, 21.

53 Steininger, 'What's Human Rights'; Alvarez, Boundaries of Investment Arbitration.

54 CMS Gas Transmission Co v. Argentine Republic, ICSID Case No. ARB/01/8, Award, 12 May 2005. 
was the question of the 'applicable law'. ${ }^{55}$ While the investor regarded the BIT and international law as lex specialis, Argentina not only considered its constitutional order relevant but also superior to the BIT. Drawing on its constitution, public law and international customary rules on state of necessity, Argentina said that obligations to safeguard constitutional rights prevailed over its BIT commitments, including investor's fair and equitable treatment (FET) claims. ${ }^{56}$ Argentina situated and construed the relation between the legalities at play within an order where constitutional public law and human rights had primacy over investment treaties.

Drawing on a 'more pragmatic and less doctrinaire' approach and 'taking the facts of the case and the arguments of the parties into account ${ }^{57}$ the tribunal concurred with Argentina that both the international and the domestic legal orders applied to the dispute. It found 'a close interaction between the legislation and the regulations governing the gas privatization, the Licence and international law, as embodied both in the Treaty and in customary international law. ${ }^{58}$ While the tribunal emphasized that the multiple legalities were 'inseparable', it also specified that they were to be applied 'to the extent justified'. ${ }^{59}$ As a consequence, the tribunal decided against Argentina that 'while treaties in theory could collide with the Constitution, in practice this is not very likely ${ }^{60}$ and 'in this case, the tribunal does not find any such collision' partly because 'there is no question of affecting fundamental human rights when considering the issues disputed by the parties' ${ }^{61}$ The tribunal highlighted that 'the specific domestic legislation of Argentina and rules of international law applied by the Tribunal will be discussed in connection with the issues contended'. ${ }^{62}$ By assigning a specific 'role' to domestic and international law in relation to the 'facts' of the dispute, the tribunal created distance between these legal orders. It insisted on regarding the two laws as separate legal orders that could simultaneously apply in the circumstances of the case, rather than creating a hierarchical

55 Ibid., para. 109.

56 Ibid., para. 114.

57 'It is no longer the case of one prevailing over the other and excluding it altogether. Rather both sources have a role to play'. Ibid., para. 116-18.

58 CMS Gas Transmission., above, para. 117.

59 Ibid., para. 117.

60 Ibid., para. 120.

61 Ibid., para. 121.

62 Ibid., para. 122. 
relation between them, as if the obligations owed to the investor and to the Argentinian population could run in parallel.

\subsubsection{Proximity and Distance}

NGOs have played an important role in tying human rights and ISDS. For example, they have highlighted conflicts between human rights and investment protection norms, as reflected in the Glamis dispute. ${ }^{63}$ The case was initiated by a Canadian mining company, investing in the United States, claiming that the mandatory backfilling requirements adopted by California violated its right of FET and of protection from 'expropriation without compensation', under chapter 11 of the North American Free Trade Agreement (NAFTA). ${ }^{64}$ Indigenous communities inhabiting the surrounding areas were affected by the investment project.

Although the United States remained silent on the relation between NAFTA chapter 11 and Indigenous rights, representatives from the Quechan Indian Nation situated the dispute within a wider juridical context including the international legal framework for the protection of Indigenous cultural heritage rights. ${ }^{65}$ They argued that the tribunal ought to 'be guided by' Indigenous people's norms when interpreting investors' rights to avoid an 'arbitrary and discriminatory decision' that would violate 'international law'. ${ }^{66}$ They employed the flexible interface norm of 'taking into account', expressed in article 31(3)(c) of the Vienna Convention on the Law of Treaties (VCLT), through which they weaved together article 1105 (minimum standard of treatment), article 1110 (compensation for expropriation) of NAFTA and the rights of Indigenous people. They also referred to the need of ensuring consistency with 'public international law' within which they situated the multiple legalities. Yet the tribunal's interpretation of its mandate had the effect of narrowing down the relevant laws at play, thereby creating distance from other bodies of norms. ${ }^{67}$ Based on the understanding that its task was to undertake a 'case-specific arbitration with awareness of the NAFTA

63 Glamis Gold, Ltd. v. United States of America, ICSID, Award, 8 June 2009.

${ }^{64}$ Ibid., para. 353.

${ }^{65}$ Glamis Gold, Ltd. v. United States of America, ICSID, Non-party supplemental submission of the Quechan Indian Nation, 16 October 2006.

${ }^{66}$ Glamis Gold, Ltd. v. United States of America, ICSID, Non-party supplemental submission.

${ }^{67}$ On the implications of this interpretative practice for the construction of relations with human rights norms, see Hirsch, Invitation to the Sociology, p. 148. 
Chapter 11 system', ${ }^{68}$ the tribunal refused to 'decide many of the most controversial issues raised in this proceeding ${ }^{69}$ and therefore did not consider the multiplicity of laws that the Quechan people invoked. Eventually, the tribunal dismissed the claims of the investor but also disregarded the claims by the Quechan people by placing emphasis on its 'case-specific mandate' and on the 'issues presented' by the parties to the dispute. ${ }^{70}$ The interpretation of investment treaty standards in the 'context' of human rights norms was on display in the Suez case, ${ }^{71}$ in which foreign investors brought claims against Argentina under three BITs. ${ }^{72}$ In this case, investors' rights to 'full protection and security' and 'fair and equitable treatment' were pitched against Argentina's human rights obligations. While the investors deemed human rights 'irrelevant' to the determination of whether the obligations under the BITs had been breached, ${ }^{73}$ five NGOs brought the right to water and to life to bear in the definition of the 'applicable law' for the 'proper adjudication of the dispute' and for the 'proper application' of fair and equitable treatment and indirect expropriation. ${ }^{74}$ They maintained that the case involved a conflict between the state's duty to protect the right to water and its obligations to the investor ${ }^{75}$ and that the former norm prevailed over the latter. ${ }^{76}$ They ordered the conflicting norms by invoking the requirement 'not to interpret certain rules in isolation from other parts of the legal order. ${ }^{77}$ According to the NGOs, the interpretation of the BIT had to take human rights law 'into account'. Similarly, Argentina framed human rights law as the 'context' in which the BIT standards had to be interpreted. $^{78}$ The tribunal's determination of the relative weight of the bodies

68

69

70

${ }^{1}$ Suez, Sociedad General de Aguas de Barcelona S.A., and Vivendi Universal S.A. v. The Argentine Republic, ICSID Case No. ARB/03/19, Decision on Liability, 30 July 2010.

72 These were the Argentine-France BIT, the Argentine-Spain BIT and the ArgentineUK BIT.

73 Suez, Decision on Liability, para. 255.

74 Centro de Estudios Legales y Sociales ('CELS') et al., 'Amicus Curiae Submission in ICSID Case No. ARB/03/19' (2007).

${ }^{75}$ On the background of the dispute see J. Calvert, 'Civil Society and Investor-State Dispute Settlement: Assessing the Social Dimensions of Investment Disputes in Latin America' (2018) 23 New Political Economy 46-65.

${ }^{76}$ Centro de Estudios Legales y Sociales ('CELS') et al., 'Amicus Curiae'.

77 On this requirement as a type of overarching norm, see Chapter 1.

78 ' $\mathrm{I}] \mathrm{n}$ order to judge whether a treaty provision has been violated, for example the provision on fair and equitable treatment', the 'Tribunal must take account of the context 
of norms at play was different from that of Argentina and the NGO. In contrast to the Glamis tribunal, which had chosen to ignore the multiplicity of laws, the Suez tribunal interpreted them as separate layers moving in parallel directions and simultaneously applicable to the factual circumstances of the case. ${ }^{79}$ As a result, it insisted on keeping a great distance between bodies of norms, which it perceived as separate and independent legal units. This particular way of ordering bodies of norms may indeed be read as a 'general reluctance [...] to openly decide potential conflicts between investment protection and public policy objectives'. ${ }^{80}$

\subsubsection{Taking into Account}

A selected integrationist perspective on the relation between investment treaty norms and human rights was articulated in the Al-Warraq case. ${ }^{81}$ The dispute originated from criminal proceedings in absentia by Indonesian authorities against an investor from Saudi Arabia holding shares in an Indonesian bank. The investor brought claims against Indonesia under a multilateral investment treaty (OIC Agreement) ${ }^{82}$ and used international human rights law to interpret its provisions. Drawing on the 'principle of systematic integration of international law norms,${ }^{83}$ the investor brought the right to a fair trial under article 14(2) of the International Covenant on Civil and Political Rights (ICCPR), the UN Human Rights Committee's General Comment 13, regional human rights institutions' pronouncements on 'presumption of innocence', ${ }^{84}$ the

in which Argentina acted and that the human right to water informs that context'. See Suez, Decision on Liability, para. 252.

79 '[A]rgentina is subject to both international obligations, i.e. human rights and treaty obligation, and must respect both of them equally'. Suez, Decision on Liability, para. 262.

80 J. E. Viñuales, Foreign Investment and the Environment in International Law (Cambridge University Press, 2012), p. 155.

${ }^{81}$ Hesham T. M. Al Warraq v. Republic of Indonesia, ICSID, Award, 15 December 2014. For a commentary, see L. Cotula, 'Human Rights and Investor Obligations in Investor-State Arbitration: Hesham Talaat M. Al-Warraq v The Republic of Indonesia, UNCITRAL Arbitration, Final Award, 15 December 2014 (Bernardo M. Cremades, Michael Hwang, Fali S. Nariman)' (2016) 17 The Journal of World Investment \& Trade 148-57.

82 Agreement for the Promotion, Protection and Guarantee of Investment among Member States of The Organization of the Islamic Conference.

${ }^{83}$ Al-Warraq, Award, para. 519.

84 The European Convention on Human Rights (ECHR), the African Commission on Human and People's Rights and the Inter-American Court of Human Rights. 
'basic rights' and the fair and equitable treatment standard under the OIC Agreement into relation. ${ }^{85}$

The tribunal concurred with the investor that certain civil and political rights were part of investment protection norms, but it distanced the notion of 'basic rights' under the OIC Agreement from human rights norms by highlighting the particular 'object and purpose' of the former (i.e. investment promotion and protection). ${ }^{86}$ However, the tribunal construed greater proximity between the FET standard and the norm against 'denial of justice' under various human rights instruments, in particular article 14(3) of the ICCPR. Eventually, the tribunal decided that 'denial of justice constitutes a clear violation of the FET standard' ${ }^{87}$ The tribunal brought ICCPR norms and the FET standard in relation after claiming that 'the ICCPR is now regarded as a part of "general international law"', which suggests that 'general international law' was used as an 'overarching norm' to connect ICCPR norms to the investment legal order. ${ }^{88}$ The Urbaser dispute ${ }^{89}$ between foreign investors and Argentina, related to a concession for water and sewage services under the terms of the Spain-Argentina BIT, partly redefined the openness of ISDS to human rights. The question of the relation between international investment agreements and human rights emerged in the context of a counterclaim by Argentina seeking compensation for damages from the investor, which affected basic human rights. ${ }^{90}$ In contrast to the Suez dispute, investors did not consider human rights 'irrelevant' but distanced them through interpretive practices. The investors claimed that human rights were duties of the state rather than of private companies and said that Argentina was under the 'obligations regarding the population's right to water, and its obligations towards international investors', which ought to be fulfilled 'simultaneously', ${ }^{91}$ reflecting the approach of the CMS and Suez awards. The investors also drew on the precedent of the Biloune v. Ghana dispute, in which the tribunal decided that 'a ruling on human rights violations is outside the scope of its

85 Al-Warraq, Award, paras 177-82.

86 Ibid., paras 519-22.

87 Ibid., para. 621.

88 On this type of interface norm, see Chapter 1. For a similar observation in the context of international trade law, see Chapter 8.

89 Urbaser S.A. and Consorcio de Aguas Bilbao Bizkaia, Bilbao Biskaia Ur Partzuergoa v. The Argentine Republic, ICSID Case No. ARB/07/26, Award, 8 December 2016.

90 Ibid., para. 1156.

91 Ibid., para. 694. 
jurisdiction'. ${ }^{92}$ While the investors emphasized the BIT, claiming that its 'provisions, principles and rights' were 'essential to resolve the dispute', Argentina maintained that the 'applicable law' consisted of the 'BIT, Argentine law and general international law' and that they ought to be applied 'jointly and harmoniously'. ${ }^{93}$ According to Argentina, the BIT was not 'a set of self-contained rules' and therefore 'international law in general' had to be applied, including 'imperative international law', which trumped standards of investment protection. ${ }^{94}$ The Urbaser tribunal responded to this situation of multiplicity by situating the legalities at play within an overarching structure. It found that 'the BIT does not represent, in the view of the Contracting Parties and its clear text, a set of rules defined in isolation without consideration given to rules of international law external to its own rules'. ${ }^{95}$ Drawing on the Tulip annulment decision, ${ }^{96}$ the tribunal listed various international human rights instruments followed by article 31(3)(c) of the VCLT and decided that 'the BIT cannot be interpreted and applied in a vacuum' and that, while it ought to be 'mindful of the BIT's special purpose as a Treaty promoting foreign investments', 'it cannot do so without taking the relevant rules of international law into account. The BIT has to be construed in harmony with other rules of international law of which it forms part, including those relating to human rights'. ${ }^{97}$ Reliance on 'overarching norms', which the tribunal implicitly construed by interpreting the provisions on applicable

92 '[W]hile the acts alleged to violate the international human rights of Mr Biloune may be relevant in considering the investment dispute under arbitration, this Tribunal lacks jurisdiction to address, as an independent cause of action, a claim of violation of human rights'. Antoine Biloune and Marine Drive Complex Ltd. v. Ghana Investment Centre and the Government of Ghana, Awards of 27 October 1989 and 30 June 1990, Yearbook Commercial Arbitration XIX (1994) p.11 (CUL-207). Cited in Urbaser., Award, para. 1129.

94 Ibid., para. 555.

95 Ibid., para. 1192.

${ }^{96}$ In the Tulip case, the investor invoked art. 6 of the ECHR on the right to a fair trial. Turkey, the respondent state, argued that the invoked provision was irrelevant in the context of the dispute as the ECHR and the ICSID Convention belonged to two 'different regimes'. In the view of the Annulment Committee, human rights were relevant and 'shall be taken into account' in light of Article 31(3)(c) of the 'VCLT'. Tulip Real Estate and Development Netherlands B.V. v. Republic of Turkey, ICSID Case no. ARB/11/28, Decisions on Annulment, 30 December 2015, paras 86-92, where the ad hoc Committee refers to the 'principle of systemic integration', stating that resort to authorities stemming from the field of human rights is a 'legitimate method of treaty interpretation'.

97 Urbaser, Award, para. 1200. 
law under article X(5) of the BIT and article 42 of ICSID Convention, enabled the tribunal to place the BIT in 'the overall system of international law'. ${ }^{98}$ Conflicting statements about the relation between international investment and human rights norms were brought forward in the Bear Creek dispute, ${ }^{99}$ involving claims by a Canadian mining company investing in a mining project in Peru under the investment chapter of the Canada-Peru Free Trade Agreement (FTA). The investment project generated acute protests by affected Indigenous communities, including the Aymara population, inhabiting the surrounding area and demanding respect for their human rights. With regard to the applicable law to the dispute, the investor and the state focused on the FTA and applicable rules of international law. ${ }^{100}$ However, two civil society organizations presented a description of the facts and of the law which highlighted connections between the Aymara population's Indigenous rights and the FTA provisions. ${ }^{101}$ The two organizations argued that Indigenous rights had to be taken into account when interpreting the FTA. $^{102}$ In his dissenting opinion, co-arbitrator Sands drew on the Urbaser award to argue that consultation requirements in article 15 of the International Labour Organization (ILO) Convention 169 were part of the 'applicable rules of international law' which the tribunal could 'take into account'. ${ }^{103}$ By failing to carry out its obligations vis-àvis the Aymara peoples' 'rights under international law', the investor contributed to the demise of the investment. Consequently, the amount of damages to be awarded was to be reduced by half. ${ }^{104}$ Although coarbitrator Sands' dissenting opinion in Bear Creek and the award in Urbaser placed a different degree of emphasis on human rights, ${ }^{105}$

98 Ibid., para. 1201.

99 Bear Creek Mining Corporation v. Republic of Peru, ICSID Case No. ARB/14/2, Award, 30 November 2017.

100 Ibid., paras 267-9.

101 The two organizations were the Association of Human Rights and the EnvironmentPuno together with Mr. Carlos Lopez, and the Columbia Center on Sustainable Investment (CCSI). Eventually, only the former organization was allowed to participate as 'other persons' under the FTA whereas the latter's application was rejected by the tribunal.

102 The CCSI placed strong emphasis on legal relationships and on the relevance of the legal context to the interpretation of the FTA. See CCSI, 'Application to File a Written Submission as an "Other Person" Pursuant to Article 836 and Annex 836.

103 Bear Creek Mining Corporation v. Republic of Peru, ICSID Case No. ARB/14/2, Partial Dissenting Opinion of Professor P. Sands, 30 November 2017, at 11.

104 Ibid., pp. 38-40.

105 I am indebted to Tomáš Morochovič for this observation. 
both statements strengthened the expectation that international investment agreements cannot be interpreted in isolation from other parts of the legal order. ${ }^{106}$ Claims about the primacy of human rights over investment protection norms were formulated by the state in the South American Silver dispute, related to an investment in mining activities in Bolivia under the terms of the United Kingdom-Bolivia BIT. The dispute stemmed from measures adopted by Bolivia to protect Indigenous communities inhabiting the areas surrounding the investment project. The parties to the dispute disagreed over the relation between the BIT and international law and between the BIT and the Bolivian national legal system. The investor deemed the BIT to be the 'primary source of law and lex specialis, as supplemented by general principles of law, as needed'. ${ }^{107}$ It distanced domestic law, arguing that it did not form part of the 'law applicable to the merits of the arbitration proceeding ${ }^{108}$ and contended that recourse to supplementary means to interpret the BIT was 'unnecessary'. ${ }^{109}$ By contrast, Bolivia demanded that a wider body of norms be taken 'in consideration' when interpreting the applicable law. ${ }^{110}$ The state said that its constitution and international norms on the protection of Indigenous rights ${ }^{111}$ were 'supplementary' to the BIT and prevailed over norms in investment treaties in case of conflict. ${ }^{112}$ The investor contested this representation, arguing that the invoked rights could not be taken into consideration by the tribunal since they were not binding on the United Kingdom and did not constitute customary international law or general principles of law. ${ }^{113}$ Having identified the BIT as 'the principal instrument ${ }^{114}$ for resolving the dispute, the tribunal found that the tool of 'systemic interpretation' under article 31(3)(c) of the VCLT is not limitless and must be applied

106 On this type of overarching norm, see Chapter 1.

107 South American Silver Limited v. Plurinational State of Bolivia, PCA Case No. 2013-15, Award, 22 November 2018, para. 187.

108 Ibid., para.193.

109 Ibid., para. 261.

110 Ibid., para. 200.

111 Bolivia referred to the 1969 American Convention on Human Rights, the 1994 InterAmerican Convention on the Prevention, Punishment and Eradication of Violence against Women, ILO Convention No.169, the 2007 United Nations Declaration on the Rights of Indigenous Peoples and the Political Constitution of the Plurinational State of Bolivia. Ibid., para. 199.

112 Ibid., para. 196.

113 Ibid., para. 190.

114 Ibid., para. 208. 
with caution. ${ }^{115}$ According to the tribunal, 'this principle must be applied in harmony with the rest of the provisions of the same article and cautiously, in order to prevent the tribunal from exceeding its jurisdiction and applying rules to the dispute which the Parties have not agreed to.'. ${ }^{116}$ Eventually, the tribunal concluded that Bolivia had to pay compensation and compound interests to the investor but dismissed all other claims of the investor.

\subsubsection{Constrained Entanglements}

The previous analysis of ISDS cases suggests that strategic, institutional and cultural factors impacted the way actors brought international investment law and 'other' legalities in relation. In a context with high institutional barriers to access and with an unequal representation of the interests involved, certain claims were accorded greater weight than other, competing ones. In particular, investment arbitrators and lawyers representing investors and states played a dominant role, whereas the voice of other affected polities was silenced.

The 'tension between proximity and distance'117 in investment treaty disputes was shaped by the interplay of a limited number of actors. Understandably, with the exception of the Al-Warraq dispute, investors had clear incentives to keep human rights law at bay in investment disputes. By contrast, states had stronger incentives to draw on that law to formulate their defences. Non-disputing parties and actors not represented in ISDS - workers, Indigenous groups, poor communities - had limited access to inform investment arbitrators' decisions. In the Bear Creek dispute, arbitrators denied a request for participation as amicus curiae by one academic institution, showing little consideration for actors other than the parties to the dispute, including disputes generating 'public interest'. ${ }^{118}$

As a consequence, entangled legalities in ISDS have mainly reflected the preferences of foreign investors, states and investment arbitrators. From this perspective, greater participation from affected outsiders ${ }^{119}$

115 Ibid., para. 212.

116 Ibid., para. 216.

117 See Chapter 1, Section 1.4.

118 Langford and Behn, 'Managing Backlash'.

119 E. Benvenisti, 'Democracy Captured: The Mega-Regional Agreements and the Future of Global Public Law' (2016) 23 Constellations: An International Journal of Critical and Democratic Theory 58-70. 
may lead to a greater variety of claims and forms of relation than the status quo allows. Yet this is unlikely to lead to entanglements that would be independent from the institutional and ideational structures of investment arbitration - enhanced participation would still operate within structural constraints.

Indeed, the analysis of ISDS cases has also shown that the multiplicity of laws was framed from the perspective of the dominant interpretive and legal frames of reference in the investment arbitration context and in conformity with the interface norms recognized within the ISDS 'community of practice'. ${ }^{120}$ In particular, investment tribunals approached multiplicity from the standpoint of international investment law by relying on the principle of 'systemic integration' in article 31(3)(c) of the VCLT. ${ }^{121}$ This principle was used to tie bodies of formal international law that were recognized by actors as the relevant law. Through this integrating principle of treaty interpretation, lawyers and arbitrators connected international investment and human rights norms by situating them within the 'system' of general international law as opposed to framing them as two separate legal systems ${ }^{122}$ and ordering them through 'reception norms. ${ }^{123}$ The dominant structures of relation observed reflect the institutional background in which ISDS lawyers have been trained and work. ${ }^{124}$ ISDS professionals' mindsets and the 'discursive policies ${ }^{125}$ in which they are situated may contribute to explaining the particular modes of ordering multiplicity in ISDS. These situated jurists seem to share a particular 'way of thinking' about the law of foreign investment arbitration, which shapes the way they practice it in relation to 'foreign' legalities. ${ }^{126}$ These actors operate in a professional

120 Brunnée and Toope, 'Interactional International Law'.

121 J. Alvarez, "Beware: Boundary Crossings" - A Critical Appraisal of Public Law Approaches to International Investment Law' (2016) 17 The Journal of World Investment \& Trade 171-228.

${ }^{122}$ R. Michaels and J. Pauwelyn, 'Conflict of Norms or Conflict of Laws: Different Techniques in the Fragmentation of Public International Law' (2012) 22 Duke Journal of Comparative \& International Law 349-76.

123 On reception norms, see Chapter 1; Michaels and Pauwelyn, 'Conflict of Norms or Conflict of Laws'.

124 On the institutional context of ICSID, see Pauwelyn, 'The Rule of Law'. On the 'investment arbitration culture', see Hirsch, 'The Sociological Dimension'.

125 Bianchi, 'Epistemic Communities', 588.

126 On how different ways of thinking about law impact legal practice, see A. Bianchi, International Law Theories: An Inquiry into Different Ways of Thinking (Oxford University Press, 2016). On the implications of actors' situatedness for the construction of entanglements, see Chapter 1. 
environment that does not create strong incentives to question the dominant schemes for thinking and practising law, much less to depart from them. For example, these specialists have to behave in conformity with the rules of the game of the institutional site in which they operate $^{127}$ in order to pursue or maintain reputation. ${ }^{128}$ These rules include shared presuppositions about the nature of 'international investment law', its 'sources', institutional circumstances and the 'rituals' ${ }^{129}$ of international arbitration. According to the recognized norms of investment arbitration, the rules on jurisdiction, applicable laws and consent of the parties have narrowed the space for linking bodies of norms in practice. ${ }^{130}$ For example, the doctrine of the limitation of tribunals' jurisdiction $^{131}$ to 'investment disputes' has enabled adjudicators to create distance between bodies of norms and strengthen the autonomy of their legal order from the interference of competing legalities. Similarly, international investment lawyers perceive that there must be 'legal grounds' for tribunals to consider human rights norms. ${ }^{132}$ ISDS insiders may benefit from the dominant mode of ordering legalities in this setting therefore there seem to be fewer incentives to change the status quo than to maintain it.

In summary, the dominant interests, institutional structures and 'legal culture $^{133}$ in ISDS seem to have influenced the way situated actors have ordered multiplicity in that setting. However, ultimate conclusions on the implications of actors' ideational context and strategic interests for the particular forms of enmeshment observed seem premature. For example, it is not clear whether investment arbitrators' background had more influence than the material incentives associated with the international investment dispute settlement culture. ${ }^{134}$ Not only did arbitrators with expertise in public international law decide in favour of foreign investors in some cases, they also kept investment protection and human rights

127 Pauwelyn, 'The Rule of Law'.

128 Schultz, 'Arbitral Decision-Making'.

129 Gaillard, 'Sociology of International Arbitration'.

130 On these rules, see Sornarajah, The International Law.

${ }^{131}$ F. Balcerzak, 'Jurisdiction of Tribunals in Investor-State Arbitration and the Issue of Human Rights' (2014) 29 ICSID Review 216-30.

132 F. G. Santacroce, 'The Applicability of Human Rights Law in International Investment Disputes' (2019) 34 ICSID Review - Foreign Investment Law Journal 136-55.

133 Hirsch, Invitation to the Sociology, p. 146.

${ }^{134}$ R. Howse, 'Venus, Mars, and Brussels: Legitimacy and Dispute Settlement Culture in Investment Law and WTO Law: A Response to Joost Pauwelyn' (2015) 109 AJIL Unbound 309-15. 
norms at a great distance from each other, against our expectations. ${ }^{135}$ This finding suggests that arbitrators' proficiency in public international law and human rights law would not automatically translate into an outcome where the distance between bodies of norms is reduced, as other factors may be simultaneously at play. For example, arbitrators' interests, including reappointment as arbitrator, may have had greater impact in shaping arbitrators' decision-making. They may have created proximity or distance between bodies of norms to pursue their own goals. In this respect, the potentially 'addictive ${ }^{, 136}$ practice of investment arbitration and the high financial stakes involved in it may have played a greater role than, or at least interplayed with, the legal background of its participants in the formation of relations between bodies of norms. From this perspective, to 'properly train' the future operators of ISDS $^{137}$ may indeed be necessary but perhaps not enough.

\subsection{Entangled Legalities at the Margins}

\subsubsection{Beyond ISDS}

Thus far, I have contextualized interpretative practices through which international investment and human rights norms have been brought in relation in investment adjudication settings. The statements of investment arbitrators and of the lawyers representing foreign investors and states have been given greater weight than those of other stakeholders, partly due to the dominant interests and ideational context of investment treaty arbitration. Civil society input has remained limited and only a few legal specialists have been authorized to determine the relative weight of legalities at play at that site. Yet ISDS is not, and should not be, the only global governance site for determining relations between these legalities. Rather, the claims of institutions and affected actors 'at the margins' of that context and its discourse should also be accounted for when appraising the enmeshment of the overall order. Against the background of the so-called 'legitimacy crisis' of international investment law, ${ }^{138}$ expressions of contestation have encouraged a reform of investment agreements

135 For example, in the CMS dispute.

136 Howse, 'Venus, Mars, and Brussels'.

137 J. Viñuales, 'Foreign Investment and the Environment in International Law: Current Trends', in K. Miles (ed.), Research Handbook on Environment and Investment Law (Edward Elgar, 2019), pp. 12-37.

138 Langford and Behn, 'Managing Backlash', 554-8. 
and investment dispute settlement. The reform process could pave the way for greater civil society input than the status quo allows, thereby creating room for closer proximity with other legalities. In this context, struggles for change within and from international investment law are situated at multiple sites and involve different actors with competing interests and approaches to reform.

\subsubsection{Reforming Investment Agreements}

At sites of treaty negotiation, states have responded to the legitimacy crisis of international investment law by rearticulating their relation with it through different lawmaking practices. While countries like Ecuador, Venezuela, Argentina and Bolivia have withdrawn or intended to withdraw from the ICSID Convention and BITs, others have amended existing investment treaties. ${ }^{139}$ The wording of these texts indicates that state parties have given human rights some consideration. ${ }^{140}$ Similar references have appeared in 'new generation international investment agreements', originally championed by the United States and Canada and subsequently adopted by the EU. ${ }^{141}$ The concept of 'governments' right to regulate', included in the 2017 Colombia model BIT as well as in the 2019 Dutch Model BIT, ${ }^{142}$ has opened a space to construe connections with states' obligations under international human rights law. ${ }^{143}$

139 M. Langford, D. Behn and O. Fauchald, 'Backlash and State Strategies in International Investment Law', in T. Aalberts and T. Gammeltoft-Hansen (eds), The Changing Practices of International Law (Cambridge University Press, 2018), pp. 70-102.

140 The 2012 US Model BIT mentions in a relatively open-ended way the interface between 'investment and the environment' (art. 12) and 'investment and labor' (art. 13); the New Zealand-Australia BIT, refers to the Treaty of Waitangi; the 2015 Norwegian Model BIT refers to the Universal Declaration of Human Rights; the 2016 BIT between Morocco and Nigeria imposes human rights obligations on investors too (art. 18). N. Zugliani, 'Human Rights in International Investment Law: The 2016 Morocco-Nigeria Bilateral Investment Treaty' (2019) 68 International and Comparative Law Quarterly 761-70.

141 C. Titi, 'International Investment Law and the European Union: Towards a New Generation of International Investment Agreements' (2015) 26 European Journal of International Law 639-61.

142 Article 7(5) states: '[ $t$ ] he Contracting Parties express their commitment to the international framework on Business and Human Rights, such as the United Nations Guiding Principles on Business and Human Rights and the OECD Guidelines for Multinational Enterprises, and commit to strengthen this framework'. For a commentary, see K. Duggal and L. van de Ven, 'The 2019 Netherlands Model BIT: Riding the New Investment Treaty Waves' (2019) 35 Arbitration International 343-74.

143 L. W. Mouyal, International Investment Law and the Right to Regulate: A Human Rights Perspective (Routledge, 2016). 
The Comprehensive Economic Trade Agreement (CETA) between the EU and Canada has brought together investment protection, trade and sustainable development and labour and environmental protection norms, and article 8.9 of its investment protection chapter reaffirms state parties' 'right to regulate'. ${ }^{144}$ Similar lawmaking practices, driven in particular by the interests of economically powerful countries, include 'mega-regulation' instruments like the Trans-Pacific Partnership that has incorporated environmental and labour norms, perhaps to address demands by civil society actors concerned with the impact of ISDS on social and environmental protection within domestic legal systems. ${ }^{145}$ Therefore, processes of investment treaty negotiations, especially if transparent and open to the participation of affected stakeholders, ${ }^{146}$ are potentially effective arenas for reshaping entanglements through textual references.

Yet, we should not read too much into these references as they tell us little about how relations with other, competing polities and their legal orders ought to be ordered. ${ }^{147}$ On the one hand, their relationship remains formally open and its shape will be determined only through political processes and the practice of societal actors. On the other hand, those references do not reflect the more contestatory claims of actors who challenge the very existence of international investment protection. While those provisions may enable linkages with 'community interests', ${ }^{148}$ it remains to be seen how the relevant decision-makers will weigh bodies of norms in practice. Under current structural circumstances in ISDS,

${ }^{144}$ Joint Interpretative Instrument on the Comprehensive Economic and Trade Agreement (CETA) between Canada and the European Union and Its Member States, 2017.

145 E. Meidinger, 'TPP and Environmental Regulation', in B. Kingsbury et al. (eds), Megaregulation Contested (Oxford University Press, 2019), pp. 175-95.

${ }^{146}$ Benvenisti, 'Democracy Captured'.

147 Similarly, references to international investment law in human rights instruments provide little guidance in this respect. Principle 9 of the UN Guiding Principles on Business and Human Rights expects state parties to investment agreements to 'maintain adequate domestic policy space to meet their human rights obligations'. The Commentary to this article is not very helpful either in its explanation that: 'States should ensure that they retain adequate policy and regulatory ability to protect human rights under the terms of such agreements, while providing the necessary investor protection.' OHCHR, 'Guiding Principles on Business and Human Rights: Implementing the United Nations "Protect, Respect and Remedy" Framework' (United Nations, 2011).

148 S. Schill and V. Djanic, 'International Investment Law and Community Interests', in E. Benvenisti and G. Nolte (eds), Community Interests Across International Law (Oxford University Press, 2018), pp. 122-48. 
characterized by a substantial preference for 'stronger rather than weaker investor protection ${ }^{\text {,149 }}$ and under-inclusiveness of relevant actors, a concrete change from dominant ways of dealing with multiplicity seems unlikely. Future practice might tell us more about the interface norms at play, and much is likely to depend on who the actors construing them will be. However, efforts at rewriting investment treaties may be seen as attempts to respond to growing voices of contestation stemming from other sites in the overall order.

\subsubsection{Human Rights Claims}

Similarly to the main type of interface norms construed in investment adjudication contexts, human rights experts have approached investment protection norms through overarching norms, which might be explained by taking account of the ideational and institutional context in which they operate. For example, in the Sawhoyamaxa case, ${ }^{150}$ involving a dispute over human rights of Indigenous communities in Paraguay, the Inter-American Court of Human Rights articulated its view of the relationship between international investment law and the Inter-American Convention on Human Rights. Paraguay sought to justify nonenforcement of the Indigenous people's property rights by arguing that the land, which had been bought by a German investor, was protected under an investment treaty between Paraguay and Germany. ${ }^{151}$ Yet the court regarded the Inter-American Convention as the ultimate frame of reference and accorded it more weight than investment agreements. It ruled that 'the enforcement of bilateral commercial treaties [...] should always be compatible with the American Convention, which is a multilateral treaty on human rights that stands in a class of its own and that generates rights for individual human beings and does not depend entirely on reciprocity among States. ${ }^{152}$ Under the presidency of Judge

\footnotetext{
149 Mattias Kumm has argued that one general presupposition of these actors is to favour 'stronger, rather than weaker investor protection'. See 'An Empire of Capital? Transatlantic Investment Protection as the Institutionalization of Unjustified Privilege', Verfassungsblog (27 May 2015), https://verfassungsblog.de/an-empire-of-capital-transat lantic-investment-protection-as-the-institutionalization-of-unjustified-privilege/.

150 Sawhoyamaxa Indigenous Community v. Paraguay, Judgment (Merits, Reparations and Costs), 29 March 2006.

151 Ibid., para. 115.

152 Ibid., para. 140.
} 
Cançado Trindade, the court's interpretation reflected a strong commitment to human rights law.

Similarly, the Office of the United Nations High Commissioner for Human Rights (OHCHR) has approached investment agreements through 'overarching norms', reflecting a conception of order under international law where human rights are accorded primacy. ${ }^{153}$ For example, the former independent expert on the promotion of a democratic and equitable international order has claimed that in case of conflict, only the highest public courts can decide in the light of the totality of international law. Until amended by States Members, the Charter of the United Nations remains the principal treaty that determines the structure and functioning of the international order. ${ }^{154}$ Therefore '[s]tates must ensure that all trade and investment agreements recognize the primacy of human rights and specify that, in case of conflict, human rights obligations prevail'. ${ }^{155}$ In the eyes of the independent expert, international investment norms and human rights were to be integrated within a hierarchical form ordered through the principle of binding character of treaties, good faith and in conformity with article 103 of the United Nations Charter. ${ }^{156}$

In its General Comment 24, the UN Committee on Economic, Social and Cultural Rights articulated a similar hierarchical conception of order between competing legalities. ${ }^{157}$ The Committee claimed that: ' $[s]$ tates parties should identify any potential conflict between their obligations under the Covenant and under trade or investment treaties, and refrain from entering into such treaties where such conflicts are found to exist, as required under the principle of the binding character of treaties'. ${ }^{158}$ The group of experts distinguished 'investment treaties currently in force' from 'future treaties'. In the first case, interpretation 'should take into

153 See Chapter 1.

${ }^{154}$ OHCHR, 'Report of the Independent Expert on the Promotion of a Democratic and Equitable International Order, Alfred-Maurice de Zayas' (2015) UN Doc. A/HRC/30/44.

155 OHCHR, 'Report of the Independent Expert', 20.

156 '[P]acta sunt servanda requires States to fulfil their human rights treaty obligations in good faith and prohibits them from entering into agreements that would delay, circumvent, undermine or make impossible the fulfilment of their human rights treaty obligations'. OHCHR, 'Report of the Independent Expert', para. 18.

157 Committee on Economic, Social and Cultural Rights (CESCR), 'General Comment No. 24 (2017) on State Obligations under the International Covenant on Economic, Social and Cultural Rights in the Context of Business Activities' (2017), UN Doc E/C.12/ $\mathrm{GC} / 24$.

158 CESCR, 'General Comment No. 24’. 
account the human rights obligations of the state, consistent with Article 103 of the Charter of the United Nations and with the specific nature of human rights obligations. ${ }^{159}$ In the second case, '[states parties] are encouraged to insert, in future treaties, a provision explicitly referring to their human rights obligations, and to ensure that mechanisms for the settlement of investor-state disputes take human rights into account in the interpretation of investment treaties or of investment chapters in trade agreements. ${ }^{160}$ The Committee's stance towards the investment protection suborder reproduced the Inter-American Court of Human Rights' approach discussed in Section 7.4.3.

Over time, human rights specialists have combined 'overarching norms' with less imposing practices aimed at persuading states to take account of their human rights obligations when making new investment agreements. One example is the 2018 initiative 'Crowd-Drafting: Designing a Human Rights-Compatible International Investment Agreement'. ${ }^{161}$ Its promoters referred to a 'human rights-based approach' to international investment treaty-making. ${ }^{162}$ Attempts at crafting a 'human rights impact assessment' norm, addressed both at states parties to international investment agreements ${ }^{163}$ as well as companies as part of their due diligence obligations, fall within these accommodation strategies. ${ }^{164}$ The United Nations Conference on Trade and Development's (UNCTAD) initiatives to investment law reform have adopted a similar approach, seeking to promote greater convergence with human rights and sustainable development norms, as exemplified by the UNCTAD's Investment Policy Framework for Sustainable Development. ${ }^{165}$ Most recently, overarching norms seem to

159 Ibid.

160 Ibid.

161 See www.ohchr.org/Documents/Issues/Business/Forum2018CrowdDrafting.pdf.

162 '[A] human rights-based approach to trade and investment entails considering how States' obligations under trade/investment law agreements might impact on their ability to fulfil their human rights obligations', see further at: www.ohchr.org/EN/Issues/ Globalization/Pages/GlobalizationIndex.aspx.

163 UNHRC, 'Report of the Special Rapporteur on the Right to Food, Olivier De Schutter. Addendum, Guiding Principles on Human Rights Impact Assessments of Trade and Investment Agreements' (2011) UN Doc. A/HRC/19/59/Add.5.

164 Columbia Center on Sustainable Development and OHCHR, 'Impacts of the International Investment Regime on Access to Justice' (Roundtable outcome document, September 2018).

165 P. Muchlinski, 'Negotiating New Generation International Investment Agreements: New Sustainable Development Oriented Initiatives', in S. Hindelang and M. Krajewski (eds), Shifting Paradigms in International Investment Law (Oxford University Press, 2016), pp. 41-64. 
have informed the ongoing struggle for a new international 'instrument' on global business and human rights, as reflected in particular in article 14 of its second revised draft, which demands that investment agreements be consistent 'with international law principles and instruments'. ${ }^{166}$

\subsubsection{Reforming Investment Adjudication}

The effects of entangled legalities have often been located in the Global South, in places where foreign investments affect local communities. At these sites, often characterized by a multilayered and scattered legal landscape where transnational and domestic bodies of norms contradict each other, ${ }^{167}$ local populations have mobilized human rights against the state and global capital. ${ }^{168}$ Local communities have contested the proximity of investment protection norms to their domestic legal order, ${ }^{169}$ but their claims have received little consideration in investment jurisprudence. ${ }^{170}$ In recent years, struggles against investment protection have become visible in the Global North, too. Particularly in Europe, citizens, environmental activists and other political actors have used contestatory mechanisms to distance investment treaties from their domestic legal orders. Protests and claims of political parties and NGOs against the intrusion of the Transatlantic Trade and Investment Partnership (TTIP), CETA and the ISDS norm into the European legal order and the constitutional order of EU member states have been one manifestation of this practice of resistance. ${ }^{171}$ In this context, European institutions and courts, too, have become important actors. The European Commission's

166 OEIGWG Chairmanship 'Second Revised Draft, Legally Binding Instrument'.

167 S. Randeria, 'The State of Globalization: Legal Plurality, Overlapping Sovereignties and Ambiguous Alliances between Civil Society and the Cunning State in India' (2007) 24 Theory, Culture \& Society 1-33.

168 B. Rajagopal, 'The Role of Law in Counter-Hegemonic Globalization and Global Legal Pluralism: Lessons from the Narmada Valley Struggle in India' (2005) 18 Leiden Journal of International Law 345-87.

169 B. Rajagopal, 'Counter-Hegemonic International Law: Rethinking Human Rights and Development as a Third World Strategy' (2006) 27 Third World Quarterly 767-83.

170 There have been calls to give more attention to these 'invisible' actors. See N. Perrone, 'The "Invisible" Local Communities: Foreign Investor Obligations, Inclusiveness, and the International Investment Regime' (2019) 113 AJIL Unbound 16-21.

171 J. Rone, 'Contested International Agreements, Contested National Politics: How the Radical Left and the Radical Right Opposed TTIP in Four European Countries' (2018) 6 London Review of International Law 233-53. See also M. Kumm, 'An Empire of Capital?'; Legal Statement on Investment Protection and Investor-State Dispute Settlement Mechanisms in TTIP and CETA, 2016. 
proposal to replace ISDS with a multilateral investment court might open a space for a wider number of actors to create different forms of relations with human rights. ${ }^{172}$ The Court of Justice of the European Union (CJEU) has recently shown a sign of resistance to investor-state arbitration by ruling that the ISDS provision in BITs between EU member states is 'not compatible' with EU law. ${ }^{173}$ By contrast, in its recent 'CETA Opinion', the CJEU has shown more openness to the prospect of an investment court system. ${ }^{174}$

In the context of ISDS reform, currently under the auspices of UNCITRAL Working Group III, the debate has focused on procedural and institutional design issues rather than on questions about the relations between investment protection and other substantive norms. ${ }^{175}$ However, some states and international institutions have emphasized connections with human rights, too. For example, in a letter addressed to participants in the ISDS reform process, human rights experts have highlighted that international investment agreements are often incompatible with international human rights law and the rule of law. ${ }^{176}$ They called for a 'fundamental systemic change' of ISDS, beyond procedural reform, and towards a 'multilateral system' that 'takes into account the rights and obligations of investors and states, in line with all applicable international laws and standards concerning human rights. ${ }^{177}$ They also claimed that greater proximity to human rights and the Sustainable Development Goals would enhance the legitimacy and effectiveness of

172 Robert Howse has concluded that 'a multilateral court system is best suited to offering standing or intervention to a wide range of actors who have concerns of international justice that relate to foreign investment'. See R. Howse, 'International Investment Law and Arbitration: A Conceptual Framework' (2017) IILJ Working Paper 2017/1 MegaReg Series 69.

173 The Court ruled that EU law precludes: 'a provision in an international agreement concluded between Member States [...] under which an investor from one of those Member States may, in the event of a dispute concerning investments in the other Member State, bring proceedings against the latter Member State before an arbitral tribunal whose jurisdiction that Member State has undertaken to accept'. Judgment in Slovak Republic v. Achmea B.V. (Case C-284/16).

174 The Court found that the international investment system is compatible with EU law. See Opinion 1/17 of the Court (Full Court) (CETA Opinion), 30 April 2019.

175 On different states' approaches to ISDS reform, see A. Roberts, 'Incremental, Systemic, and Paradigmatic Reform of Investor-State Arbitration' (2018) 112 American Journal of International Law 410-32.

176 OHCHR, 'Letter to the UNCITRAL Working Group III on ISDS Reform, Urging Systemic Changes to the ISDS System' (7 March 2019).

177 Ibid. 
the UNCITRAL process. ${ }^{178}$ The government of South Africa has also strongly advocated to take account of human rights and the principle of sustainable development. ${ }^{179}$

\subsection{Conclusion}

This chapter has analysed how relations between international investment and human rights norms have been construed in multiple global governance sites. Investment treaty arbitration has remained a central arena where foreign investors, states, investment adjudicators and NGOs have supplied competing forms of relation between bodies of norms, especially when defining the law applicable to the dispute. These relations have reflected the preferences and the ideational context of the actors involved in their construction.

In the majority of cases examined, the claims of investment arbitrators, investors and states have been given greater consideration than the claims by NGOs and the public at large, limiting room for contestation. Foreign investors have sought to narrow the scope of relevant bodies of norms whereas states and NGOs have aimed at expanding it. Over time, ISDS participants, and investment adjudicators in particular, have tended to regard relations with human rights norms with less hesitancy. Although the decisions of investment tribunals affect many constituencies, possibilities for these affected outsiders to make their claims heard in investment arbitration have been limited. Their priorities have often been silenced in sites of investment treaty negotiation too.

The analysis has observed an evolution in the way actors have dealt with human rights in ISDS over time, although dialectic tendencies of proximity and distancing persist. Initially, foreign investors adopted a clear rhetoric against the relevance of human rights in ISDS. In a second phase, they recognized their relevance but they kept them at a distance to downplay any potential conflict with investment protection standards. As states began to refer to human rights norms in their defences, investment tribunals had to find ways to articulate relations with them. The current phase seems marked by a very limited reliance on human rights on the part of investors and tribunals and more frequent linkages construed by

178 Ibid.

179 United Nations Commission on International Trade Law et al., 'Possible Reform of Investor-State Dispute Settlement (ISDS) Submission from the Government of South Africa' (2019) UN Doc A/CN.9/WG.III/WP.176. 
states and NGOs, thereby creating entanglement on a rhetorical level but one constantly undercut by using other tools to create distance. In most of the cases examined, ISDS participants have used 'overarching norms' to order legal pluralism within international law, which may be explained by reference to the cultural and institutional context of ISDS. However, the dominant use of this 'interface norm' has not led to a new, fully integrated system as considerable contestation persists in other parts of the legal order. Indeed, forms and dynamics of entanglement have become observable in struggles 'at the margins' of and beyond the bounds of ISDS. These forms of contestation have led to a process of reform of international investment agreements and investment adjudication that may create room for shaping new forms of relations with human rights. However, only the future practice of actors will tell us how they will be construed. In the different contexts examined, the practice of taking other norms 'into account' has been one of the main tools for ordering multiplicity, yet without determining the substantive outcome of the practice of giving regard to other bodies of norms. Even when using this interface norm, ISDS participants have had discretion to determine the relative weight of the legalities brought together. Human rights actors have also had recourse to a similar interface norm when articulating their views of the relation with investment agreement, but their vision of legal order differs from the one put forward in the practice of investment arbitration. 